\title{
Incorporating Multicultural Literature in EFL Classroom
}

\author{
Vidya Mandarani ${ }^{1}$, Ahmad Munir ${ }^{2}$ \\ ${ }^{1}$ Universitas Negeri Surabaya, Universitas Muhammadiyah Sidoarjo, Indonesia. e-mail: \\ vidya.20002@mhs.unesa.ac.id \\ 2 Universitas Negeri Surabaya, , Indonesia. e-mail:ahmadmunir@unesa.ac.id
}

\begin{tabular}{|c|c|}
\hline ARTICLE INFO & ABSTRACT \\
\hline $\begin{array}{l}\text { Keywords: } \\
\text { diversity awareness, } \\
\text { multicultural education, } \\
\text { multicultural literature }\end{array}$ & $\begin{array}{l}\text { Nowadays' multicultural education poses various challenges. One of the } \\
\text { latent issues currently emerged in Indonesia education is the mistreatment } \\
\text { towards the students of minority ethnic amongst the fellow learners. This } \\
\text { status quo pushes schools' stakeholders to reflect upon their responsibilities } \\
\text { and reconsider the use of multiculturalism in enhancing diversity awareness } \\
\text { towards both teachers and students. In an attempt to promote multicultural } \\
\text { education, the use of multicultural literature that portrays various cultures, } \\
\text { values, and views, may assist the students in appreciating their own culture } \\
\text { by the acquisition of diverse perspectives of the society. Moreover, it provides } \\
\text { potential teachers to comprehend the diversity of multicultural issues beyond } \\
\text { mono-cultural perspectives. This paper aims to emphasize the significance of } \\
\text { multicultural literature as teaching materials; recommend selection and } \\
\text { evaluation criteria for the said literature; as well as to present strategies of } \\
\text { formulating literature-based classrooms. In providing the best teaching } \\
\text { materials, it is necessary to select high-quality multicultural literature to } \\
\text { present accurate and authentic representations of cultural communities. At } \\
\text { any rate, 1o overall criteria should be embedded within the selected literature, } \\
\text { thus the QuILT metric can be utilized to assess its quality. Afterward, there } \\
\text { are also several recommended approaches, techniques, or strategies for } \\
\text { formulating a literature-based classroom that may promote critical thinking } \\
\text { in literary discussion. }\end{array}$ \\
\hline \multicolumn{2}{|c|}{$\begin{array}{l}\text { How to cite: } \\
\text { Mandarani, V. \& Munir, A. (2021). Incorporating Multicultural Literature in EFL Classroom. Indonesian } \\
\text { Journal of English Language Teaching and Applied Linguistics, 6(1), 1-12 }\end{array}$} \\
\hline
\end{tabular}

\section{Introduction}

The discourse of multicultural education was primarily too American-biased since it has the same conception with human rights movements from various oppressed groups of people in the said nation (Khairuddin, 2018). Indonesia is a nation that is long-known for its multicultural values embody differences in almost every aspect of life and will remain this way in the foreseeable future. Despite that, we live in a progressively globalized world, as technological growth has closed the gap of connections. In the current 21st century, we can no longer afford to only look inward, by learning anything just from the literature that reflects 
our points and our own world's sphere. Then we are challenged to reconsider some perspectives and take a globalized point of view on varying social, economic, scientific, and intellectual issues.

In this case, multicultural education may become an approach in altering values that are capable of honouring and educating humans (Agustian, 2019). Also, to promote multiculturalism and promises a hope to change the framework of our current educational institutions to all students, male or female, gifted or impoverished, major ethnics or minorities, without any exceptions will have an equal chance to achieve academic support in a school (Smolen \& Oswald, 2010). For multicultural education endorsement, reading materials embedded in a classroom should be able to represent the diverse member of that said classroom. As a matter of fact, multiculturalism in the Indonesian society contexts has long been a fascinating discourse to be brought into various literary works. That is why multicultural literature is a pivotal part and resource of this movement to assist diverse perspectives acquisition.

As multicultural literature has created its way into the English curriculum, it demands the teachers to develop their cultural knowledge and enhance their sensitivity. Also, to improve the teaching skills in conducting classroom discussions that encourage cross-cultural understanding and using multicultural literature to validate the manifestation of cultural knowledge, standpoints, and diversity (Dong, 2005). All students also ought to witness their positive representations alongside their culture in literature. English has long been preferring as a source of intercultural communication for people from diverse cultural and linguistic backgrounds since it is a lingua franca. English is used in various cultural phenomena to exchange ideas or share experiences. Without the proper understanding of behaviour and cultural setting of language use, it may lead to failure and misinterpretation in communication, or it may cause errors and misunderstandings as well (Ali et al., 2015).

Hence, multicultural literature serves as a strategic and significant object of study in an attempt to tackle national problems (Taufiq, 2014). Its integration may offer an opportunity to incorporate varying cultures into the classroom. As we primarily understand that Indonesia is a haven of diversity, that is the reason why Indonesian teachers of English language subjects should consider using multicultural literature to promote diversity awareness among all students. Several studies have presented evidence that multicultural literature can highly motivated students. Lawrence et al. (2017) observed pre-service teachers of the urban elementary classroom who developed students' literacy through multicultural literature. Their finding showed that students whore engaged in multicultural literature with authentic linkage to learning are likely to obtain more successful learning outcomes. Bedard \& Fuhrken (2019) discovered that middle schoolers may engage in characters' journeys, truly develop an appreciation and consideration for the text and acquire the depth of cultures. Presenting culturally responsive teaching is teachers' main concern, yet many of them are unaware of the advantages of multicultural texts that may affect their classroom because their lack of understanding, as well as readiness, may significantly influence students' learning.

From his study on children's literature books towards 17 educators in a 5-days range on a care centre sited around Perth metropolitan area, Adam et al. (2019) discovered that most educators possessed a limited understanding of the role of literature in disclosing and appreciating diversity, as well as hardly use these books to endorse diversity-related outputs 
of Early Years Learning Framework (EYLF), which are children around 0-5 years. Similarly, Mcnaughton (2020) investigated the capability of secondary students in using critical literacy techniques and develop empathy for oppressed and marginalized communities through the use of multicultural literature. The outcomes showed that students were, normatively unwilling to engage in critical discussions that involve personal stance and perspective probing; students were also hesitant to engage in discussions that may potentially hurt their classmates. Historical context and content familiarity may also play a role in encouraging or preventing students' critical literacy perspective during a small group discussion. These two studies reinforce the need for cultural awareness for teachers before their teaching routine. They need to be able in contextualizing both fiction and non-fiction multicultural literature in historical, political, or social events; as well as to facilitate critical conversation in meaningful ways. They should not reject non-dominant cultural identities and deny diversities. Such rejection and denial will negatively affect the students' perception of diversity, which further will hamper their academic achievements, while also cultivating ignorance by stressing the insignificance of cultural identities (Davis, 2016).

In the Indonesian context, integrating multicultural values into early childhood education contributes a significant impact. Various educational institutions from primary schools to universities possess a role in promoting multicultural values in students. Sudigdo et al. (2020) attempted to delve into the essence of multiculturalism in two poem collection books; Sehimpun Puisi. Resep Membuat Jagat Raya and Keragaman Budaya Indonesia, that are composed by elementary school students. The findings showed that each poem comprises at least fourteen values of multiculturalism, including mutual respect for cultural equality, social class, ethnicity, gender, language, religion, race, appearance, pluralism, rights, customs, behaviour patterns, education, and tolerance. This activity should motivate other teachers to introduce the values of multiculturalism in children at an early stage. Further, providing multicultural children literature in higher education is crucial to present the examples of work analysis with the tendency of multiculturalism values and to be used as the teaching instrument of writing poetry in elementary school (Sudigdo et al., 2018).

Above all else, multicultural literature possessed mostly an important role to play in such influence. Students need to be able to make connections between literature and their everyday lives (Colby \& Lyon, 2004). Reading about the world's diversities will provide readers with perspectives and settings, which enable them to imagine and consider a wider world beyond their own. Literary works consist of several genres, such as traditional literature, historical fiction, realistic fiction, picture books, poetry, modern fantasy, and science, as well as informational books and biography (Temple et al., 1998). No doubt, there is an important contribution of cultural awareness in foreign language learning programs. To enable a culture in empowering the identity of the nation, learners must be directed to conduct a reinterpretation of the multicultural values possessed by a particular nation or state. It is necessary to expose learners to a cultural context by creating interactive activities through language teaching strategies.

Regarding those aforementioned studies of multicultural literature that inspire the similar use in English department students in Indonesia, to bring an education that values and uphold the perspective of diversities, this paper is aimed to strengthen the importance of multicultural literature; to recommend criteria of selection and evaluation for the related 
multicultural literature; as well as to present strategies for formulating literature-based classroom.

\section{Multicultural Literature}

Literature is not only to make students appreciate a story and be seen as a work of art but also it must be seen as a tool for advancing an ideology (Goo, 2018). Multicultural literature is the kind of literature that represents an ethnic, urban, or diverse multicultural perspective and therefore can process a dualistic approach in conceptualizing identities and strengthening the cultural background (Davis, 2016). Despite the challenges of the all-white literature domination due to the existence of multicultural literature, the perspective of marginalized ethnic group, as the new category of literature, represent their world by portraying their voices and images (Cai, 2002). That is the reason why it is often regarded as the literature of minority cultures (Bista, 2012). The lack of multicultural literature in classroom activities may lead to urgent social issues today (e.g. racism). The use of inclusive literature that signifies diversities helps to provoke a prideful sense in children and affirms the identity of their families as well as communities (Adam et al., 2019). Such finding is also shown in Husband's experiment where he employed multicultural picture books to teach children in the classroom and expose them to a large spectrum of information related to all racial groups in societies (Husband, 2018).

On the other side, children and teenagers are exposed to the alternative cultural perspective that acts as a challenge against their behaviour and belief when they read multicultural literature. Thus, Gripton (1993) explained that students who read multicultural literature will start to realize that all ethnic groups possess roots in the past and all have valid heritages that contribute to the overall culture. Though there are times when students of minorities struggle with reading and are less likely to get engaged during the classroom activities when they do not see themselves of their cultured being represented in the literature (Youngs, 2015).

The students' relation and their enthusiasm upon literature-any written literature regarding or by ethnic minorities-as well as their critical voice of secluded and sporadic inclusion of multicultural literature address the necessity of a new appearance on English literature instruction and curriculum. Multicultural literature inclusion in a curriculum is the initial step in the attempt to recognize the diversities (Slaughter, 2021), to find self-worth (Rapp, 2019), and to attain education equity above all else. It delivers the story through minority voices to address and express authentic cultural content through issues of freedom, socio-cultural experiences, historical aspects, and racial identity (Davis, 2016).

Therefore, to work with various learners, all teachers ought to possess a cross-cultural understanding and deliver a culturally delicate curriculum. Teachers should also endorse the awareness of diversity in schools so that every single child will feel welcomed and tend to respect others, as well as to learn the subject meaningfully in accord to the direct relation to real life in a global society (Iwai, 2019). Developing multicultural viewpoints over the study of multicultural literary text gives an instrument to create multicultural behaviour and awareness (Taufiq, 2014). These texts will later encourage students to create meaning and analyze the literature through a critical perspective. By their inquiry, learners start to observe their experience and see its complexity, while confounding issues connected to privilege and power. They constructed a good foundation in an attempt to act against their aggressors (Osorio, 2018). Through this means, the use of multicultural literature in EFL classrooms may 
highly motivate students to be life-long readers who can appreciate the reality of human diversity and to have empathy with people of other cultures since they become familiar with their inner world (Moecharam \& Sari A, 2014). Students learn to accept and be more aware of cultural shifts within societies and often embrace them (East \& Thomas, 2007). Finally, more majority students of can grasp, view, and understand the other outlooks as well as perspectives on life (Youngs, 2015).

Multicultural literature as a stance (reflect belief) and affects literature choices, including how the literature will be used, the addition of multicultural literature within a curriculum enhances the classroom context for learning on essential means as it validates the culture of individual students and develops the respect or understanding for other cultures that may lead to social actions (Smolen \& Oswald, 2010). They may learn to express their feelings and thoughts, as well as what is critical that they need to share with their peers. In stimulating students' cultural sensitivity, the teachers ought to possess knowledge of various genres in literary works. Temple et al. (1998) divided the genres into traditional literature, picture books, poetry, realistic fiction, historical fiction, modern fantasy, and science fiction, along with informational books and biography. All of these literary forms possessed their histories of discussion and development (Hanauer, 2003).

Concerning literary forms and English language teaching, the study from Bournot-Trites et al. (2007) emphasized that a drama in an ESL context may enhance written and communicative skills, learning motivation, as well as a socio-cultural understanding of the target language. The study advised that a drama may induce a positive learning environment, which promotes collaboration and encourage students to participate in linguistic, emotional, as well as intellectual sense of the way. Additionally, Yon (2020) examined that poems in a multicultural English class can assist students to grasp the sense of respect and belonging in a classroom. Both teachers and students may work and learn from each other to promote equitable and culturally responsive experiences. Brenneman (2018) who analyzed several educational movies directed and produced by American natives found that movies can be an excellent start to discuss others' culture, values, and language. Blake \& Cashwell (2004) who observed the use of poetry in a university education model showed that the participants tended to be more receptive to the model in which they feel that they have profited and to witness the increased awareness of sensitivity upon the impact of gender and culture in defining the realities of other participants, which further elevate students' cultural sensitivity.

Particularly for Indonesians, reading diaspora literature, which is written by Asian descent will assist readers not only in elevating their language skills but also in enhancing the diversity awareness that they're experiencing as nation citizens (Sitepu, 2017). Diasporic writings, which encompass experiences of immigrants living in foreign land help readers understand multiculturalism as a reality. Moreover, Arifin \& Susanto (2018) recommend using narrative stories and pantun jenaka (a type of humorous poem) that are filled with a nation's character and cultural values. The choice of narrative stories can be in a form of 2000 s Indonesian literary novels that deal with several contexts, including nations, ideas, views, cultures, as well as religions, such as Ayat-Ayat Cinta. This story has multicultural attitudes from the perspective of character development, which can be good examples for the Indonesian and the world's society in general. These can also be used as the media to suppress various harmful ideologies like radicalism or terrorism in any form including ideas or behaviour (Supratno et al., 2018). 
While there may be an increasing acknowledgment of the importance of textual integration in expanding students' experiences, the choices of text that represent the diversities themselves are challenging. Brown (2021) explained that powerful literature may bring students to a world where they may experience the joy and struggle of others, as well as where they may constrain the cultural landscape a character lives in. Our effort to bring the students onto these journeys has significantly grown lately thanks to the impact of multicultural literature on children and young adults. Therefore, it is necessary to provide the students with reading materials to engage them with the most appropriate text for their reading level (Yokota, 2009).

\section{Selection and Evaluation of the Qualified Multicultural Literature}

As one of the primary resources of multicultural literature, Cooperative Children's Book Center (2021) recorded a noticeable growth of books by and/or about black, indigenous, and people of colour about $6 \%$ since 2018 . Embedding the first culture of minority groups by integrating the literature of indigenous people, immigrants, and their descendants into the EFL curriculum, which is necessary to empower the students and suppress both racism and hetaerism, aiming to endorse acceptance of diversity, cross-cultural understanding, as well as civic responsibility (Honigsfeld et al., 2011), to promote critical thinking by examining and delving the topics from multiple perspectives. This shows that multicultural literary works are essential in students' preparation for the changing world.

This means that there is a way for English language teachers to leverage diversity awareness through multicultural literature. Since not all literary works are published with the same high calibre, one ought to consider a cautious selection for different classroom contexts. It is required to select qualified multicultural literature to give authentic and accurate portrayals of cultural communities. Moreover, accurate illustrations enable readers to portray how characters interact and act in a story; how they preserve and observe their traditions; how they celebrate a special moment; how they feel in their varying surroundings and environments (Iwai, 2015). In an attempt to precisely tell a story of multicultural literature, the author ought to come from within the group about which s/he is writing (Bista, 2012). Only members of the inferior race who possess the life experience to talk regarding racism (Goo, 2018).

Further, Temple et al. (1998) suggested that multicultural literature should embody: (1) positive characters imagery with realistic behaviours and authentic cultural perspectives; (2) multidimensional to assist readers in experiencing the depth and breadth of a certain culture; (3) cultural details that embedded naturally; (4) historical accuracy when appropriate; (5) dialect or language spoken by the characters should authentically portray the interactions; (6) impactful visual and authentic illustration; (7) pluralistic them to nurture belief in cultural diversities as a national asset and reflect the changing population; as well as (8) high literary quality, including superb plots and well-developed characterizations. To improve these, Iwai (2015) added two points to be integrated into the books, namely: (9) evasion of tokenism and stereotyping, so the readers may gain in-depth knowledge of people and culture in their context; as well as (10) variety of genres, where teachers ought to try to include folktales, poetry, historical fiction, biographies, contemporary realistic, and even picture books, so then students or children of older grade may personally relate by reading what they are 
interested in. This framework is meant to give a starting point from which teachers may explore the various aspects of multicultural literature.

Besides that, one of the quick and easy tools to assess the quality of a certain text is through the use of QUILT metric, which refers to Quality of writing; Universal theme; Imaginative plot; Lesson plan; as well as Talking points (Slaughter, 2021). These points assist teachers to evaluate and choose multicultural literature that aligns with the standard curriculum. Highquality multicultural literature encompasses stories of all classes, races, religions, abilities, sexualities, and often marginalized groups. It should also contain various themes, genres, and characters. Teachers should avoid books with offensive expressions, negative attitudes, or stereotypical representation, and avoid any piece of literature that shows a single cause and/or simple solution to the world's socio-historical dilemmas of the culture being represented (Rapp, 2019). Each book should ideally reflect the nation's diversity and universality of human experience. For young readers, specifically for those who are living in a rather homogenous community, these books may be their only experience of multicultural interaction (Slaughter, 2021). The process of learning literature as a means of internalizing the culture of the nation should involve and be carried by various parties, specifically parents, teachers, as well as society (Arifin \& Susanto, 2018).

Hence, teachers need to make informed decisions when they choose multicultural literature, from the type of texts to the types of questions that lead to student inquiry. The following examples are a recommendation of multicultural literature for primary to intermediate levels that are taken from some recent studies: (a) Traditional Folktale: The Well of Truth (2008); How Tiger Got His Stripes (2006); (b) Novels: Grown (2020); Dear Justyce (2020); The Hate U Give (2017); Ayat-Ayat Cinta (2003), Bumi Cinta (2010), Sang Pembaharu: Perjuangan dan Ajaran Syaikh Siti Jenar (2012), and Api Tauhid (2014); (c) Picture Books: Hair Love (2019); Last Stop on Market Street (2015); Each Kindness (2012); Warna-warni Cerita Seru dari Raja Ampat (2017); Kisah dari Alor (2017); Kisah dari Sumba (2018); (d) Professional Texts: The Civically Engaged Classroom: Reading, Writing and Speaking for Change (2020); We Got This: Equity, Access, and The Quest to be Who Our Students Need Us to be (2018); (e) Poetry: Around the World in Eighty Poems (2001), Poems to Dream Together (2005); (f) Films: American DREAMers (2015); Black Girl in Suburbia (2016), and many others.

\section{Implementation of Multicultural Literature in the Classroom}

Embedding multicultural literature in a classroom practice may assist students in imagining the lives of others and through this chance, a process of envisioning the perspective of diverse cultural groups may be initiated (Howlett et al., 2017). On other hand, school stakeholders also ought to pursue due diligence in searching for multicultural literature that is appropriate for a classroom and aligned with the school's objective (Slaughter, 2021).

In an attempt to encourage the use of multicultural literature in the classroom, Iwai (2015) proposed additional tips mentioned as follow: (1) model of positive behaviour towards diversity, where teachers may treat all students fairly and teach them to treat others as well as their peers the same without stereotypes or biases, which further will allow the students to realize the importance of interaction and understanding upon people of different background. It encourages proper development of awareness of diversity; (2) the choice of high-quality multicultural books; (3) effective instructions planning, where teachers need to be prepared in asking interpretative and applicable questions-the questions need to be 
considered to develop their diversity awareness and harness their critical thinking, identify the lesson aims, as well as to properly communicate with the students; (4) the use of crosscurriculum books. To differentiate instructional approach, teachers ought to utilize discussions webs and readers' theatre. Other recommended approaches are sketch-tostretch double-entry journals, open-mind portraits, interactive writings, and storyboards. One can use a Venn diagram as an effective graphic organizer for compare-contrast activities; (5) networking building, where interaction, especially face-to-face contact, enables students in gaining more in-depth ideas on both people and various cultures. Lu (2021) advised that teachers can expect to consult with parents, colleagues, and even local ethnic communities, to absorb their specialized knowledge and peculiar perspectives.

Howlett et al. (2017) also proposed 4 (four) instructional strategies proposed by Banks to integrate a multicultural understanding into the curriculum, which is detailed as follow (1) Contribution Approach, which aims at an external approach to culture, such as holidays, heroes, and other cultural elements; (2) Additive Approach, which provides students to view concepts, theme, content, and perspectives without altering the curriculum structure; (3) Transformative Approach, where the curriculum is altered to enable students seeing the issues, concepts, events and themes from the perspective of cultural groups and diverse ethnic; as well as (4) Social Action Approach, where the curriculum is adjusted to accommodate students' decision making of important social issue and take action to tackle them.

The role a teacher takes during literature discussion encourages students to talk, share personal connections and reflect on their lives. A teacher needs to critically analyze the reasoning behind what they do and make sure it matches the outcome they desire. Even students who had been labeled with "low proficiency"; our conversation helped them feel more comfortable, see themselves in the curriculum, and explore their multiple identities. They were acquiring the tools and space to unpack complex issues in their lives (Osorio, 2012, 2015). Krafick (2020) proposed a method to endorse the use of multicultural literature is by cultivating schools' libraries, which in return will serve as reading materials that students may read, appreciate and recognize culture as well as the background where they came from. The more students engaged with textual sources, the better readers they will become (Howlett \& Young, 2019).

Additionally, guiding learners to discover answers to questions, the teachers can apply a cultural response guideline when responding or reading to a text. Such a cultural response perspective allows the students to feel the character and look at the issues from the characters' point of view. By adding the approach of cultural response, enhancing students' cross-cultural understanding, and engaging students in texts' cultural contexts exploration, teachers can nurture considerate discussion that explores various issues of culture, identity, and literature. According to Rass (2020), to differentiate the method of students involvement within a course, several lessons may be initiated with a free writing activity, where the participants are invited to write about the events or main characters and share their writing in a group, in which the group may respond to quote from the stories. From these methods, approaches, or strategies, teachers may select the best one for a classroom activity so long as it assists the students in imagining the lives of others and by this experience, the envisioning process of perspectives for diverse cultural groups, ethnics and equity in education may be initiated and achieved. In response, EFL teachers would improve their 
images as individuals in a certain minority group and their role would not be restricted to both instruction and pedagogy. They will become the agents of social reform in this world.

\section{Conclusion}

As the haven of diversity, nurturing the students' diversity awareness in school is indeed imperative. Through the use of multicultural literature, teachers may broaden the students' world to various events, histories, peoples, and cultures, as well as assist the students in gaining insights to reflect on their own culture. Embedding multicultural literature in the EFL classroom is a starting phase to promote diversity awareness. Teachers who are assigned to teach multicultural literature ought to possess adequate preparation in both knowledge and the use of multicultural literature as teaching materials itself. In today's diverse classroom conditions, the teacher should uphold equity, exemplify a positive attitude model, carefully chose high-quality literary forms, as well as prepare effective instructional strategies with proper approaches as well as objectives. They also ought to integrate various kinds of multicultural differences, including identity, gender, and political alignment into their teaching across the curriculum.

Along with that consideration, it is Indonesian literary works may become a viable option in promoting multiculturalism in the classroom context. The use of indigenous literary works may present a more relatable perspective, hence will further propel multiculturalism education. Hopefully, teachers may be able to assist the students in developing their intercultural competence and literacy skills in appreciating their own and others' cultures, honour students' voices, be connected to students' cultural backgrounds and rich linguistic, as well as to promote critical consciousness of multiculturalism. In response, the EFL teachers will become the agents for social reform in this world.

\section{References}

Adam, H., Barratt-Pugh, C., \& Haig, Y. (2019). "Portray cultures other than ours": How Children's Literature is Being Used to Support The Diversity Goals of the Australian Early Years Learning Framework. Australian Educational Researcher, 46(3), 549-563. https://doi.org/10.1007/s13384-019-00302-w

Agustian, M. (2019). Pendidikan Multikultural. Unika Atma Jaya.

Ali, S., Kazemian, B., \& Mahar, I. H. (2015). The Importance of Culture in Second and Foreign Language Learning. Dinamika Ilmu, 15(1), 1-10. https://doi.org/10.2139/ssrn.2656713

Arifin, J., \& Susanto, H. (2018). The Internalization of Multiculturalism Values through Literature Learning. 1st International Conference on Social Sciences Education (ICSSE 2017), 147, 167-169. https://doi.org/10.2991/icsse-17.2018.38

Bedard, B. C., \& Fuhrken, C. (2019). Deepening Students' Reading, Responding, and Reflecting on Multicultural Literature: It All Started with Brown Girl Dreaming. The Texas Council of Teachers of English Language Arts, 49(1), 25-31.

Bista, K. (2012). Multicultural Literature for Children and Young Adults. Educational Forum, 76(3), 317-325. https://doi.org/10.1080/00131725.2012.682203

Blake, M. E., \& Cashwell, S. T. (2004). A Model for Use of Poetry in Diversity Education. Journal of Poetry Therapy: The Interdisciplinary Journal of Practice, Theory, Research and 
Education, 17(1), 9-20. https://doi.org/10.1080/08893670410001698497

Bournot-Trites, M., Belliveau, G., \& Spiliotopoulos, V. (2007). The Role of Drama on Cultural Sensitivity, Motivation and Literacy in a Second Language Context. Journal for Learning through the Arts, 3(1). https://doi.org/10.21977/d93110058

Brenneman, R. (2018). Reviews of Educational Films. Multicultural Perspectives, 20(1), 37-38. https://doi.org/10.1080/15210960.2018.1408332

Brown, B. B. (2021). A Guide to Selecting Multicultural Literature. Teaching Africa. https://www.bu.edu/africa/outreach/teachingresources/literature-languagearts/selection_guide/

Cai, M. (2002). Multicultural Literature for Children and Young Adults: Reflections on Critical Issues (1st ed.). Greenwood Press.

Colby, S. A., \& Lyon, A. F. (2004). Heightening Awareness about the Importance of Using Multicultural Literature. Multicultural Education, 10(1), 1-7.

Cooperative Children's Book Center. (2021). Children's Book by and/or about Black, Indigenous and People of Color. Books by and/or about Black, Indigenous and People of Color 2018. https://ccbc.education.wisc.edu/literature-resources/ccbc-diversity-statistics/booksby-and-or-about-poc-2018/

Davis, S. L. (2016). How Multicultural Literature Effects African American Students' Literary Responses. St. John Fisher College.

Dong, Y. R. (2005). Bridging the Cultural Gap by Teaching Multicultural Literature. Educational Forum, 69(4), 367-382. https://doi.org/10.1080/00131720508984709

East, K., \& Thomas, R. L. (2007). Across Cultures: A Guide to Multicultural Literature for Children. Libraries Unlimited.

Goo, Y. (2018). Multicultural Literature Education: A Story of Failure? Society, 55(4), 323-328. https://doi.org/10.1007/s12115-018-0262-x

Gripton, B. (1993). Multicultural Literature: The Need for Inclusion. Grand Valley State University.

Hanauer, D. I. (2003). Multicultural Moments in Poetry: The Importance of the Unique. The Canadian Modern Language Review, 6o(1), 69-87. https://doi.org/10.3138/cmlr.60.1.69

Honigsfeld, A., Giouroukakis, V., \& Garfinkel, J. L. (2011). Immigrant Literature in the Secondary English Classroom: Rationale and Recommendations. California Reader, 44(3), 25-31.

Howlett, K. M., Bowles, F. A., \& Lincoln, F. (2017). Infusing Multicultural Literature into Teacher Education Programs: Three Instructional Approaches. Multicultural Education, 24(3-4), 10-15.

Howlett, K. M., \& Young, H. D. (2019). Building a Classroom Library Based on Multicultural Principles: A Checklist for Future K-6 Teachers. Multicultural Education, 26(3-4), 40-46.

Husband, T. (2018). Using Multicultural Picture Books to Promote Racial Justice in Urban Early Childhood Literacy Classrooms. Urban Education, 1-27. https://doi.org/10.1177/0042085918805145

Iwai, Y. (2015). Using multicultural children's literature to teach diverse perspectives. Kappa Delta Pi Record, 51(2), 81-86. https://doi.org/10.1080/00228958.2015.1023142

Iwai, Y. (2019). Culturally Responsive Teaching in a Global Era: Using the Genres of Multicultural Literature. Educational Forum, 83(1), 13-27. https://doi.org/10.108o/00131725.2018.1508529

Khairuddin, A. (2018). Epistemologi Pendidikan Multikultural di Indonesia. Ijtimaiyah, 2(1), 1- 
20.

Krafick, K. (2020). Cultivating Classroom Libraries that Promote Multicultural Literature.

Lawrence, S. A., Johnson, T., Baptiste, M., Caleb, A., Sieunarine, C., \& Similien, C. (2017). PreService Teachers' Use of Multicultural Literature. Journal of Inquiry and Action in Education, 9(1), 28-47.

Lu, M.-Y. (2021). Multicultural Children's Literature in the Elementary. Race; Lee \& Low Books. https://www.leeandlow.com/educators/race/multicultural-children-s-literature-in-theelementary-classroom

Mcnaughton, D. G. (2020). Utilizing Multicultural Literature to Foster Critical Literacy in a Secondary English Classroom [Rowan University]. https://rdw.rowan.edu/etd/2775

Moecharam, N. Y., \& Sari A, R. D. N. K. (2014). Let's Talk and Tolerate: Strengthening Students Cultural Awareness through Literature Circles. Indonesian Journal of Applied Linguistics, 3(2), 117-127. https://doi.org/10.17509/ijal.v3i2.662

Osorio, Sandra L. (2018). Multicultural Literature as a Classroom Tool. Multicultural Perspectives, 20(1), 47-52. https://doi.org/10.1080/15210960.2018.1408348

Osorio, Sandra Lucia. (2012). Letting Go: The Multiple Roles of a Teacher in Literature Discussions. Journal of Classroom Research in Literacy, 5, 3-15.

Osorio, Sandra Lucia. (2015). "¿Qué es deportar?" Teaching from students' lives. Rethinking Schools, 30(1), 28-32. https://rethinkingschools.org/articles/que-es-deportar-teachingfrom-students-lives/

Rapp, J. (2019). Using Multicultural Literature to Enhance the Reading Skills of Youth of Color [State University of New York]. https://digitalcommons.brockport.edu/ehd_theses

Rass, R. A. (2020). Integrating Multicultural Literature in EFL Teacher Training Curriculum. Open Journal of Modern Linguistics, 10(5), 588-598. https://doi.org/10.4236/ojml.2020.105035

Sitepu, I. V. (2017). Studying Multicultularism through Readings of Diasporic Writing: Indonesian Way of Learning Differences and Diversity. Textual Mobilities: Diaspora, Migration, Transnationalism and Multiculturalism, 45-49. http://repository.uki.ac.id/1818/

Slaughter, R. (2021). Turning the Page: The Ultimate Guide for Teachers to Multicultural Literature. Rowman \& Littlefield.

Smolen, L. A., \& Oswald, R. A. (Eds.). (2010). Multicultural Literature and Response: Affirming Diverse Voices. ABC-CLIO.

Sudigdo, A., Slamet, S. Y., Winarni, R., \& Ekowardani, N. (2020). Multiculturalism in Children's Literature: A Study of Poetries by Elementary School Students. Humanities \& Social Sciences Reviews, 8(3), 246-259. https://doi.org/10.18510/hssr.2020.836

Sudigdo, A., Slamet, Winarni, R., \& Ekowardani, N. (2018). The Urgency of Multiculturalism in Children's Literature Textbooks in the Industrial Revolution 4.0. ICSTI. https://doi.org/10.4108/eai.19-10-2018.2282178

Supratno, H., Kamijan, \& Raharjo, R. P. (2018). Multiculturalism in 2000 Indonesian Literary Novels from the Perspective of Character Building: Sociology of Literature Study. 2nd Social Sciences, Humanities, and Education Conference (SoSHEC 2018), 222, 396-399. https://doi.org/10.2991/soshec-18.2018.84

Taufiq, A. (2014). Multicultural Literature: the Identity Construction in Indonesian Novels. Jurnal Humaniora, 26(1), 22.

Temple, C., Martinez, M., Yokota, J., \& Naylor, A. (1998). Children's Books in Children's Hands: 
An Introduction to Their Literature. Allyn \& Bacon.

Yokota, J. (2009). Learning Through Literature That Offers Diverse Perspectives: Multicultural and International Literature. In D. A. Wooten \& B. E. Cullinan (Eds.), Children's Literature in the Reading Program: An Invitation to Read (3rd ed., pp. 66-73). https://doi.org/10.1598/0699.07

Yon, A. (2020). Theme for English H: Identity Poems in a Multicultural English Class. New Jersey English Journal, 9.

Youngs, E. (2015). Effects of Multicultural Literature on Children 's Perspectives of Race And Educator Implementation of Multicultural Literature [St. John Fisher College]. 